\title{
The four seasons of a fading mind
}

Matthew Lennon, MD

Neurology ${ }^{\circledR}$ 2018;91:274-275. doi:10.1212/WNL.0000000000005943

Spring

Sunset dappled warm, pink and purple 'cross your smiling creased face As we talk of creaking joints and laugh about your old and funny ways Then you ask me "Where are you going?" eyes searching, quizzically And I say "I've told you three times Nana," in confused disbelief

A thousand colours bloom and blossom, in a flood kaleidoscopic When you rang me, lost while driving, though I knew you were myopic I knew you knew those streets better than the dorsum of your hand A seed of worry planted in the smooth suburban footpath of our lives and of our plans

Summer

The sun bore down like blankets made of lead and iron and hessian The haze of heat it shimmered morphing what is real, to false impressions As you scrawl on paper things you never would forget

And I wondered if this haze was hiding cracks in the road that may grow deeper yet

For creeping through those cracks, so slight, was a chaos of your mind Which was mirrored in your house things. It was impossible to find Your prized flowers amongst the weeds, but it was summer still So we left the weeds to grow and thrive, and tried to enjoy the pleasure pasttimes with which our days we'd fill

\section{Autumn}

Like leaves, dusky and brittle, that snap with the winds of change Autumn bought you a storm of moods that flickered from elation then to rage And tears like rain inconsolable, inexplicable, you couldn't verbalize That hurricane that filled your head or the tears that filled your eyes

The cracks now chasms, left you standing on the cliffs of your frustration There was no way to bridge the gaps but to cling to ropes of confabulation You'd assure me that this morning you'd been from here to Timbucktoo And though I'd say "That's not possible," you'd decided in your mind, that in the absence of other memory, it simply must be true

\section{Winter}

Winter bit, left us sleepless and froze right to our hearts

As you screamed nightly of insects that crawl on walls and threaten in the dark No longer sure of where you were, as the gloom stretched backward over your years

And took you back, to relive so childlike, all your childhood fears

\section{Correspondence}

Dr. Lennon

matthew.lennon@

unsw.edu.au

MORE ONLINE

ค Audio

Listen to Dr. Lennon read this poem.

NPub.org/bqsbvb 
And came your fall and then the recognition, we couldn't manage you alone And though it tore the family from hip to shoulder, we found a nursing home There you faded, like winter trees, as indolence sapped your brain

And for Mum you died, before your death came near, when on that cold morning you did not know her name

Spring

The sunrise, crisp and golden touches your calm, creased face

Like Gods' radiant, open arms calling, waiting for embrace

And though memories of screams and rage have left our minds with scars

We hold on to those old times, and the knowledge that your disease isn't who

you are 


\title{
Neurology
}

\author{
The four seasons of a fading mind \\ Matthew Lennon \\ Neurology 2018;91;274-275 \\ DOI 10.1212/WNL.0000000000005943
}

This information is current as of August 6, 2018

\section{Updated Information \& Services}

Subspecialty Collections

Permissions \& Licensing

Reprints including high resolution figures, can be found at: http://n.neurology.org/content/91/6/274.full

This article, along with others on similar topics, appears in the following collection(s):

All Cognitive Disorders/Dementia

http://n.neurology.org/cgi/collection/all_cognitive_disorders_dementia Alzheimer's disease

http://n.neurology.org/cgi/collection/alzheimers_disease

Cognitive aging

http://n.neurology.org/cgi/collection/cognitive_aging

MCI (mild cognitive impairment)

http://n.neurology.org/cgi/collection/mci_mild_cognitive_impairment

Information about reproducing this article in parts (figures,tables) or in its entirety can be found online at:

http://www.neurology.org/about/about_the_journal\#permissions

Information about ordering reprints can be found online:

http://n.neurology.org/subscribers/advertise

Neurology ${ }^{\circledR}$ is the official journal of the American Academy of Neurology. Published continuously since 1951, it is now a weekly with 48 issues per year. Copyright (O 2018 American Academy of Neurology. All rights reserved. Print ISSN: 0028-3878. Online ISSN: 1526-632X.

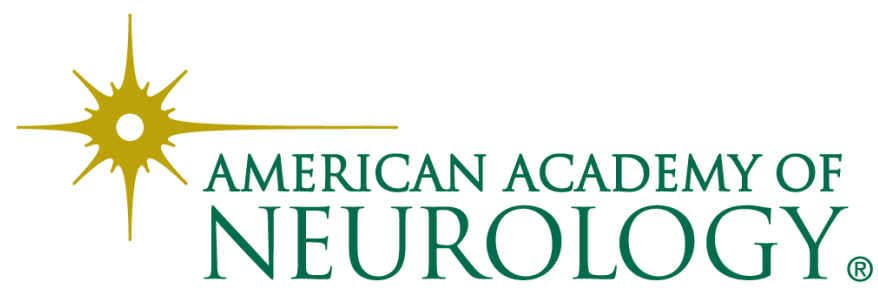

